\title{
PERTO DO CORAÇÃO SELVAGEM, DE CLARICE LISPECTOR: ROMANCE DE ERRÂNCIA SUBJETIVA
}

\author{
Gilson Antunes da Silva ${ }^{1}$
}

\section{RESUMO}

Tomo, como objeto de estudo, o romance Perto do coração selvagem, de Clarice Lispector, a fim de evidenciar como as escolhas de Joana pela aventura do caminho reverberam o mito do Judeu Errante e esboçam o topos da errância na obra ficcional da autora. Leio a poética inaugural de Lispector como romance de errância subjetiva. Destaco três aspectos dessa diáspora subjetiva presentes na obra: errâncias objetal, espacial e estrutural.

\section{Palavras-Chave}

Perto do coração selvagem. Clarice Lispector. Romance de errância subjetiva.

\section{1) INTRODUÇÃO}

A literatura produzida por Clarice Lispector (1920-1977) radica-se no campo das subjetividades em que as paixões são representadas em seu estado de força e crueza, revelando personagens contraditórias, desassossegadas e inadaptadas com a realidade na qual estão inseridas. Isso é recorrente em toda a produção da autora em que há uma galeria de personagens que desfilam em sua errância rumo a uma existência autêntica, a uma reconciliação com as pulsões vitais encobertas por um cotidiano quase sempre aquém dessa vontade que as anima. Essa errância fica muito evidente no primeiro romance cuja heroína caminha desenfreada rumo ao coração selvagem, horizonte jamais alcançado, esse porto sem cais que a desafia desde a infância (SILVA, 2018).

Perto do coração selvagem é publicado em fins de 1943 pela editora A noite e é constituído por duas partes. Na primeira, dividida em nove capítulos, há dois planos narrativos que se alternam: o da infância e o da vida adulta de Joana, personagem central.

\footnotetext{
${ }^{1}$ Doutor em Literatura e Cultura (UFBA), Mestre em Letras (UFBA), Especialista em Língua Portuguesa e Literatura Brasileira (FACCEBA), em Ensino de Língua e Literaturas de Língua Portuguesa (UNIMES), em Teoria da Psicanálise de Orientação Lacaniana (BAHIANA/IPBA), licenciado em Letras (UNEB) e bacharel em Filosofia (UCSal). Professor do IF Baiano (Valença), membro do Grupo de Pesquisa em Linguagens, Culturas e Ambientes (GLICAM) e da Academia Valenciana de Educação, Letras e Artes (AVELA). E-mail: gilsonfi@bol.com.br.
} 
Sua história é montada em flashes, em que são apresentadas suas fantasias infantis ao lado do pai, de um amigo de seu pai que resgata algumas informações acerca de Elza, mãe da garota, já falecida. Narram-se, também, nessa parte, o contato conflituoso com a tia que a adotara após a morte do pai e a puberdade de Joana, em situações problemáticas. Há ainda outros flashes da vida adulta de Joana que se alternam com os da infância, como o cotidiano da personagem já casada com Otávio, o passeio com o esposo, seus momentos de epifania e o diálogo com a "mulher da voz", além de suas reflexões sobre ela. O capítulo final dessa parte associa os dois planos narrativos e retrata o sentido de seu amor. Já a segunda parte do romance, composta por dez capítulos, desenrola-se em torno do triângulo amoroso: Joana, Otávio e Lídia. Joana vive em casa amalgamada pelo horizonte doméstico e já não conta mais com o abrigo do professor, como na infância, outra figura importante com quem a heroína se identifica e constrói uma relação de amor. Otávio, por sua vez, tinha uma amante, sua ex-noiva, Lídia, que estava grávida. Ao descobrir isso, a protagonista não fez escândalos passionais, conversa com a rival, e, em seguida, Otávio a abandona. Depois da separação, um desconhecido passa a seguir Joana, eles têm alguns encontros, mas, tempos depois, ele acaba também partindo, empurrando Joana de encontro à solidão prevista na epígrafe do livro retirada de Joyce: "Ele estava só. Estava abandonado, feliz, perto do selvagem coração da vida" ${ }^{2}$. A narrativa finaliza com a personagem feliz com esses abandonos, quando ela se considera liberta e capaz de sentir o mundo em sua plenitude, certa de que "daí vinha sua vida e seus momentos de glória e daí vinha a criação de cada instante futuro" (LISPECTOR, 1998, p. 196). Joana também embarca sozinha numa viagem indefinida, e o livro finaliza num grande monólogo interior em que se confundem a voz da protagonista com a do próprio narrador.

A literatura de Clarice Lispector encena um campo das relações humanas marcado por conflitos existenciais e representa o sujeito em sua errância, lançado no mundo como ser de um desejo insatisfeito que se sustenta na sua própria insatisfação. Perto do coração selvagem evidencia essa relação entre o ser de falta e as demandas de completude do desejo, resultando numa travessia incansável em direção ao objeto, ao núcleo do coração selvagem. Segundo Benedito Nunes (2004), esse romance evidencia a peregrinação do desejo insatisfeito, convertido num movimento de errância, numa intérmina busca.

Flagro, neste texto, um momento em que Joana se debate entre a frustração e o desejo, a vida e a morte (naquilo que denomino encruzilhada existencial) e assume a

\footnotetext{
${ }^{2}$ Retiro a tradução que aparece na edição aqui utilizada.
} 
aventura do caminho como possibilidade de existir e de continuar sua peregrinação rumo à vida mais larga. A partir dessa escolha pela aventura do caminho, objetivo evidenciar como Clarice Lispector faz reverberar o mito do Judeu Errante em sua escrita, fazendo emergir, em sua obra, o topos da errância. Leio a obra como romance de errância subjetiva e destaco alguns aspectos que confirmam essa tese: a errância do objeto (que considero o elemento principal da dispersão subjetiva de Joana), o nomadismo espacial e a errância estrutural da própria obra. Faço este estudo a partir da Literatura comparada, entrecruzando os discursos literário, filosófico e psicanalítico. Para atingir esse objetivo, divido o texto em duas partes. Na primeira, tomo Joana em uma de suas encruzilhadas existenciais, para evidenciar o diálogo com o mito do Judeu errante e a emergência do topos da errância. Em seguida, desdobro os três aspectos dessa errância presentes no romance: o do objeto, o da diáspora espacial e o da dispersão estrutural.

\section{2) REEDIÇÃO DO MITO DO JUDEU ERRANTE EM CLARICE LISPECTOR}

Recorto, para esta leitura, os últimos capítulos da narrativa, quando a heroína clariciana, já adulta, após a morte dos pais e a partida dos homens com quem tivera algum tipo de relação amorosa, depara-se com o horizonte vazio do desejo e-consequentemente - com a necessidade de fazer escolhas subjetivas para decidir os rumos de sua travessia.

A vida de Joana é marcada, ao longo do todo o romance, por uma tensão inconclusa, remetendo-a a experiências que a levam ao amadurecimento subjetivo e, ao mesmo tempo, a um sofrimento psíquico untado de tortura e glória. Tomada por essa força constante, Joana é atraída, inconscientemente, para as armadilhas do desejo e da pulsão e sente, no movimento desejante, seu ponto de gozo. Nietzsche, em $A$ vontade de poder (2008), defende a ideia de que essa tensão inconclusa é o próprio estímulo para a vida, e não o seu ponto de dor. Para o filósofo, o sentimento de prazer jaz justamente no não-apaziguamento da vontade, no fato de que ela, sem limites e resistências, ainda não está satisfeita o bastante. No aforismo 697 desse livro, ele expressa tais ideias da seguinte maneira:

O não-apaziguamento normal de nossas pulsões - por exemplo, da fome, da pulsão sexual, da pulsão de movimento - ainda não contém em si nada de desalentador; atua, antes, irritando o sentimento de vida, assim como todo ritmo de estímulos pequenos e dolorosos o fortalece, o que também os pessimistas podem atestar: esse não- 
apaziguamento, em vez de prejudicar a vida, é o grande estimulante da vida. (NIETZSCHE, 2008, p. 352)

Esse apaziguamento impossível é representado, na narrativa, até as últimas linhas do texto. Nos capítulos finais, isso se torna mais incisivo. Cansada de trilhar por veredas sempre frustradas pela opacidade do real, Joana hesita em continuar nessa procura, mas adentra na dimensão caótica e se entrega numa viagem rumo ao insondável, lançando-se no eterno devir, lugar onde o desejo é sempre desejo de outra coisa, desejo de desejo, o que, segundo Lacan (1997), constitui sua dimensão essencial.

Antes desse gesto afirmativo, porém, a protagonista vacila entre afirmar ou negar a existência, mergulhando numa verdadeira encruzilhada existencial, experimentando seu Getsêmani inadiável. A voz narrativa, aqui, utiliza essa estratégia de postergação do encontro faltoso com o objeto, a fim de intensificar o desejo da protagonista. Para isso, faz a heroína recuar em sua travessia, levando-a a perceber, na morte, uma possibilidade de satisfação, encontro com o Outro absoluto, mergulho no todo. Depois que todos partem (Otávio e o amante), e ela tem que se assumir, definitivamente, como ser castrado e, a partir desse deserto interior, fazer mais uma escolha frente à tragicidade existencial, Joana pensa em abandonar-se à morte, "ceder de seu desejo" e acabar, terminantemente, com sua peregrinação. "Haveria de reunir-se a si mesma um dia, sem as palavras duras e solitárias... Haveria de se fundir e ser de novo o mar mudo brusco forte largo imóvel cego vivo. A morte a ligaria à infância" (LISPECTOR, 1998, p. 190).

Deparar-se com o vazio da castração traz a Joana angústia e sofrimento, como aparece neste fragmento da narrativa: "Agora de novo um círculo de vida se fechava. E ela na casa quieta e silenciosa de Otávio, sentindo sua ausência em casa lugar onde no dia anterior ainda haviam existido seus objetos e onde agora havia um lugar vazio ligeiramente empoeirado" (LISPECTOR, 1998, p. 187). Há, nesse fragmento, uma percepção clara dos sinais de perda que se impõem sobre a face de Joana. Alguns significantes colaboram para a construção dessa aura de ruínas, como "ciclo de vida que se fechava", "casa quieta e silenciosa" "ausência", "lugar vazio ligeiramente empoeirado". Frente a frente com essa "hora perigosa da tarde",

\footnotetext{
${ }^{3}$ Trata-se de uma expressão usada em “Amor”, de Laços de família (1997) para evidenciar o medo de Ana em deparar com o momento de vazio, com o real da castração que se insinua nos objetos e na casa limpa e arrumada. Tanto Joana (nesse momento) quanto Ana fogem dessa íntima desordem. À personagem do conto será dada a possibilidade de retornar à vida apaziguada; à Joana, do contrário, resta o mergulho na desordem subjetiva, na aventura do caminho, o mesmo feito por G.H. e pela narradora de Água viva (1973).
} 
impossibilidade de continuar desejando, pois, conforme Lacan (2002, p. 117), "aquilo do que o sujeito teme ser privado, é de seu próprio desejo".

Por ser o desejo puro movimento, isso implica num projeto contínuo que absorve as energias pulsionais do sujeito e o liga à realidade de forma mais direta. Por outro lado, diante da ausência de um desejo a ser enunciado, o sujeito afasta-se desse registro, tornando-se angustiado e melancólico. Essa melancolia corresponde à zona de apagamento, de desaparecimento desse movimento incessante que sustenta a vida do homem, tornando sua existência sem sentido, sem rumo. Segundo Sandra Edler (2008), é diante dessas condições que o sujeito, costumeiramente, evoca a figura da morte, simbolizando, por meio dela, a possibilidade de acabar com a dor e a tristeza encontradas nesse estado de passividade. Ainda conforme a autora, quando o sujeito está fora do registro do desejo, a vida perde seu principal atrativo: os dias são vividos na manutenção da sobrevivência, no cumprimento das obrigações e nas inúmeras providências que povoam o cotidiano; a vida resume-se ao puro existir, ou melhor, à dor de existir, o que, muitas vezes, precipita o sujeito para a morte.

A morte, aqui, mais uma vez, insinua-se, insiste, repete-se e torna a digladiar com Eros, seu rival. Thanatos não baixa suas armas nesse jogo sem interrupções, mas, ao contrário, seduz a heroína, apontando o coração selvagem para além do princípio de prazer. Joana, como a maioria das personagens claricianas, estão na mira de Thanatos, são seres no horizonte da morte e para ela caminham. O embate está, mais uma vez, estabelecido. O conflito subjetivo impõe-se em sua intensidade sobre a heroína em crise que precisa escolher um caminho, ainda que provisório. Ir, sobretudo, em frente, é a meta de Joana, o que redunda em sua hybris. A hybris ou desmedida é algo do campo do excesso, ímpeto violento e desenfreado que se sobrepõe ao controle racional do sujeito. Benedito Nunes (1989), ao ler Perto do coração selvagem, utiliza esse conceito como culpa trágica, resultado de um excesso, de uma desmesura. Trata-se de uma possibilidade humana e corresponde à infinitude do desejo; é um perigo demoníaco que se acha na insaciabilidade do apetite que sempre deseja duplicar o que tem, por muito que isto seja.

Depois da imersão nessa crise em que a morte aparecia como horizonte para o sujeito, a heroína suspende o desejo de ruínas, esboçando para si mais um projeto de vida:

Corria agora à frente de si mesma, já longe de Otávio e do homem desaparecido. Não morrer. Porque... na verdade onde estava a morte dentro dela? - indagou-se devagar, com astúcia. Dilatou os olhos, ainda não acreditando na pergunta tão nova e cheia de deslumbramento que se permitira inventar. Caminhou até o espelho, 
olhou-se - ainda viva! O pescoço claro nascendo dos ombros delicados, ainda viva! - procurando-se. Não, ouça! ouça! não existia o começo da morte dentro de si! E como atravessasse o próprio corpo violentamente, em busca, sentiu levantar-se de seu interior uma aragem de saúde, todo ele abrindo-se para respirar. (LISPECTOR, 1998, p. 191)

Essa nova escolha vai-se, aos poucos, tomando forma numa gradação ascendente e domina todo o corpo da personagem numa espécie de gozo diabólico: "O coração batendo com força, ouviu-se atenta. Riu alto, um riso trêmulo e gorjeado. Não..." (LISPECTOR, 1998, p. 191). Entretanto, ainda restam dúvidas por qual vereda subjetiva adentrar, mas o querer viver de novo a conduz por esboços de caminhos que se delineiam na própria travessia. E, como andarilho, Joana precipita-se, mais uma vez, na aventura do caminho:

\begin{abstract}
Sobrevivera como um germe ainda úmido entre as rochas ardentes e secas, pensava Joana. Naquela tarde já velha - um círculo de vida fechado, trabalho findo -, naquela tarde em que recebera o bilhete do homem, escolhera um novo caminho. Não fugir, mas ir. Usar o dinheiro intocado do pai, a herança até agora abandonada, e andar, andar, ser humilde, sofrer, abalar-se na base, sem esperanças. Sobretudo sem esperanças. (LISPECTOR, 1998, p. 196)
\end{abstract}

Joana, novamente, parece recuar, embora o desejo de continuar sua trajetória ainda seja seu objetivo primeiro ("Não fugir, mas ir"). Ela parece desistir da possibilidade de uma vida excessiva e cruel e voltar-se para o aniquilamento dos instintos, da força, da vontade de poder, por meio da humildade, do autossofrimento, do abandono da vitalidade e do egoísmo.

Diante da impetuosidade da vida e de todas as adversidades dela advindas, Joana opta - ainda que momentaneamente - pela peregrinação, pela humildade, pelo sofrimento, pela renúncia. Segundo Nietzsche (2001), essa opção, no fundo, esconde um desejo de poder e domínio sobre os outros que permanece camuflado e reprimido. Aquele que renuncia,

aspira a um mundo mais elevado, ele quer voar mais, mais longe e mais alto que todos os homens da afirmação - ele joga fora muitas coisas que atrapalhariam seu voo, e entre elas coisas que lhe são valiosas e queridas: sacrifica-as à sua ânsia das alturas. Esse sacrifício, esse jogar fora, é justamente aquilo que se torna visível nele: por causa disso chamam-no de aquele que renuncia, e como tal ele nos aparece, envolto em seu capuz, como se fosse a alma de um cilício. Mas ele está satisfeito com a impressão que faz em nós: quer 
manter oculta a sua ânsia, seu orgulho, sua intenção de voar acima de nós. (NIETZSCHE, 2001, p. 77)

A imagem do andarilho, do peregrino, representada no trecho clariciano ("e andar, andar, ser humilde, sofrer, abalar-se na base, sem esperanças. Sobretudo sem esperanças”) aproxima-se, por metonímia, da noção de andrajos, maneira como o peregrino se traveste em sua jornada. Esse símbolo condensa duas ideias diferentes e complementares. Segundo Chevalier e Gheerbrant (2006), há, nessa imagem, a noção de uma pobreza disfarçada, principalmente, nos contos de fadas, quando, no fundo, ela encobre um ser superior, como príncipes, reis, etc. Além disso, o andrajo disfarça a riqueza interior sob aparências miseráveis, aquele tesouro escondido, "alguma coisa [...] que se disfarça, que está onde menos se espera" (LISPECTOR, 1999, p. 17) ${ }^{4}$, evidenciando a superioridade do eu profundo sobre o eu superficial. O narrador, aqui, parece optar pelo disfarce também, a fim de mostrar sua heroína em vacilação diante da própria trajetória. Joana é representada sob o véu do ressentimento, da negação da vida, da recusa ao destino. É posta em estado de camuflagem para, nos últimos momentos, resplandecer em sua vontade de potência, em sua afirmação pujante da existência. $\mathrm{O}$ andarilho ou o peregrino, em busca de uma purificação, caminha para um estado ideal. Toda sua travessia preparao para uma iluminação, para a revelação divina, que são a recompensa no final da viagem. Para Joana, do contrário, não há recompensa nem final de viagem. Ela é uma personagem trágica e, como tal, sua conta não fecha, uma vez que não há reconciliação entre seus conflitos subjetivos e o que a realidade lhe oferece. Desse descompasso tantálico, como afirmara Antonio Candido (1977), resta-lhe o desamparo e a solidão, estados tomados, no final da narrativa, como estratégias para afirmação da própria vida (SILVA, 2015).

Nesse momento da narrativa, Clarice Lispector faz reverberar, em sua escrita, o mito do Judeu Errante. Figura trágica como Prometeu e Sísifo, O Judeu Errante, segundo Marie-France Rouart (2005), está condenado a vagar, sem repouso, até o Julgamento Final. Para esse viajante maldito, "a imortalidade sobre a Terra torna-se paradoxalmente

\footnotetext{
${ }^{4} \mathrm{O}$ tesouro escondido é o objeto em torno do qual gira a produção da aluna Sofia, protagonista do conto "Os desastres de Sofia", de A legião estrangeira (1999). O professor havia solicitado que redigisse um texto dando continuidade a esta história: "um homem muito pobre sonhara que descobria um tesouro e ficara muito rico; acordando, arrumara sua trouxa, saíra em busca do tesouro; andara o mundo inteiro e continuava sem achar o tesouro; cansado, voltara para sua pobre, pobre casinha; e como não tinha o que comer, começara a plantar no seu quintal; tanto plantara, tanto colhera, tanto começara a vender que terminara ficando muito rico" (LISPECTOR, 1999, p. 15). A menina, para confrontar o mestre, acaba indo em direção contrária, abordando o tesouro como algo a ser descoberto e se encontra onde menos se espera, a ser "cavado no interior de si mesmo, nos sujos quintais de cada um, o que supõe um trabalho, embora de outra natureza". (ROSENBAUM, 2006, p. 61)
} 
a sanção mais terrível que pode atingir um homem, uma vez que o exclui de toda afeição humana e faz com que ele veja tudo à sua volta morrer, desaparecer e renascer" (ROUART, 2005, p. 665). Para a autora, é preciso distinguir dois grandes períodos na evolução do enredo acerca do mito dessa figura. O primeiro confunde muitas tradições, favorecendo a difusão de um relato contaminado pelas lendas e pelos mitos de caráter bíblico ou profano. Nessa fase, a errância do herói assume valor alegórico, revelando o desejo de explicar a própria condição do homem. O segundo período (a partir do século XVIII) carrega a lenda de um simbolismo diversificado que transforma em vagar problemático um vagar alegórico, sem exaurir a inspiração tradicional.

Como ponto de partida, tem-se, no Judeu Errante, a figura de uma testemunha da paixão de Cristo que, tendo sobrevivido ao drama do Calvário, erra pelo mundo afora. Já a tradição popular (fixada no século XVIII por uma crônica inglesa) elabora a imagem de um sobrevivente condenado a errar por ter esbofeteado Jesus ou a aguardar a vinda do Senhor nos finais dos tempos. Para Mathieu Paris, em sua Chronica Majora, um certo Cartáfilo, presente à Paixão, teria empurrado o Cristo no caminho do Calvário, gritandolhe: “Vá! Vá!”, e, em compensação, teria sido condenado a aguardar a volta do Salvador. De cem em cem anos, ele retoma a idade que tinha na ocasião daquele encontro e não pode mais perder sua vida porque perdeu sua morte. Nessa construção, prevalecem dois significantes centrais: o insulto à divindade e a espera indeterminada. No final do século XVI, a lenda aparece no solo alemão, tendo, no centro, um velho judeu, sapateiro por profissão, com família e denominado Ahasverus, dizendo-se condenado a andar até o final dos tempos para servir de testemunha viva contra os judeus e os incrédulos. Numa terceira etapa da evolução da lenda, a Balada Brabantina (1774) rebatiza o Judeu Errante de Isaac Laquedem. O final do século XVIII é o momento decisivo para a transformação da imagem, dando ao herói uma ascendência mítica, comparando-o a Caim, o primeiro fratricida. O caráter errante de Ahasverus passa a simbolizar a condição de todo sujeito em seu enfrentamento com o espaço e o tempo. O Judeu Errante é o homem que, entregue a seus demônios interiores, é capaz de transformar sua maldição em redenção. Ao longo do século XIX, sob a influência do niilismo pós-romântico, Ahasverus simboliza cada vez mais toda existência marginal, tanto individual quanto coletiva. A partir do Romantismo em sua primeira fase, aparecem e coexistem, segundo Rouart (2005), três orientações essenciais no simbolismo do Judeu Errante, orientações que põem a nu imagens primordiais de visão, de revolta e de salvação. 
Joana e a maioria das protagonistas de Lispector atualizam o mito do Judeu Errante no que diz respeito à caminhada ininterrupta e sem repouso. Tal qual esse viajante maldito, a protagonista de Perto do coração selvagem jamais encontra um ponto de sustentação para seu caminhar, o que a precipita na travessia perene. Condenada pelo desejo a errar em torno do coração selvagem à procura da Terra Prometida, Joana insiste, qual Danaides, a encher um vaso que nunca se completa. Nessa viagem recorrente, ela também vê, qual Tântalo, tudo ao redor nascer, florescer, morrer para, mais uma vez, renascer.

O seu drama é o de Tântalo, sempre pensando tocar o alvo e sentindo-o sempre fugitivo. Com a diferença que para Tântalo isso era condição de desespero, enquanto que para ela nisto residia a própria razão de ser da vida e, portanto, a sua glória, a sua esplêndida unicidade. (CANDIDO, 1977, p. 130)

Há uma diferença na errância das duas figuras em pauta. O Judeu caminha, mas tem a esperança de um término, ainda que distante. Quando Cristo retornar, no dia da Parusia $^{5}$, todo sofrimento acabará, a viagem, portanto, chegará ao fim. Há, aqui, ainda que distante, uma esperança de redenção vinda do Outro. E, com isso, o caminhar, ainda que solitário, tem a presença de uma companhia ausente. Joana, sujeito moderno desamparado, pelo contrário, caminha só, sem deuses, sem "consolos metafísicos", contando apenas consigo mesma nessa tarefa inadiável. "Mas das profundezas como resposta, [...] ergueu-se a chama queimando lúcida e pura... Das profundezas sombrias o impulso inclemente ardendo, a vida de novo se levantando informe, audaz, miserável”. (LISPECTOR, 1998, p. 199)

Ao aproximar esse mito com a errância de Joana, focalizando na imagem da viagem muito presente na ficção lispectoriana, leio Perto do coração selvagem como um romance da errância subjetiva ${ }^{6}$. Berta Waldman (2003), ao analisar a novela Viagens de Ahasverus à terra alheia em busca de um passado que não existe porque é futuro e de um futuro que já passou porque sonhado, de Samuel Rawet, discute o conceito de novelas de errância e as apresenta como o relato que inclui personagens que vagueiam pelo mundo, cruzando a terra e o mar, sem aparente propósito nem destino. Nessas novelas antigas,

\footnotetext{
${ }^{5}$ Parusia: termo empregado em sentido técnico para designar a visita cerimonial de um soberano a uma cidade ou país, ou para aparição de um deus para prestar auxílio. No Novo Testamento, o termo é usado, às vezes, para designar a vinda escatológica de Jesus. Nos evangelhos sinóticos, a parusia é descrita como a vinda do Filho do Homem na glória, com os anjos. Será precedida por sinais nos céus e será como um relâmpago. (MCKENZIE, 2011)

${ }^{6}$ Talvez a obra romanesca de Lispector, de modo geral, possa ser pensada a partir dessa categoria.
} 
está incluído o regresso à terra natal, ou o anúncio de que o regresso é iminente, fornecendo a marca inequívoca de que se está por chegar ao fim do relato quando os viajantes se ancoram definitivamente ao mundo cotidiano, fechando-se o ciclo de suas aventuras. O texto clariciano, ainda que preso à ideia de errância subjetiva, ultrapassa esse modelo citado por Waldman, quando apresenta uma protagonista que nunca retorna ao ponto de origem. Joana apenas vai, segue viajando, sem jamais regressar a não ser por meio de uma memória fraturada e incerta. Enquanto nas novelas de errância tradicionais esse percurso geográfico é mais acentuado e, no final, reencontrado, no romance clariciano, a viagem é, predominantemente subjetiva e, além disso, contínua. O viajar joanino não conclui, assim como seu itinerário subjetivo. Nem a própria estrutura da narrativa se fecha, evidenciando essa marca errante tanto da forma quanto do conteúdo. Errante também é a escrita da autora, em busca de um dizer que sustente o vazio. Nessa errância, os textos também viajam no espaço ficcional, circulando de uma obra a outra, inserindo-se em lugares diferentes, a fim de atingir um sentido que não se dá totalmente. Nessa perspectiva, para Carlos Mendes de Sousa (2012, p. 26), "O impacto da figura da errância (da não fixação) faz-se sentir profundamente nos domínios essenciais: da situação que biograficamente marca a vivência da escritora até às mais fundas consequências que se manifestam no plano da escrita".

Segundo Benedito Nunes (1989), do primeiro ao último romance de Lispector, a ação propriamente dita desenvolve-se na forma de uma errância, tanto interior quanto exterior das personagens. Para o crítico, nos dois primeiros livros, há o itinerário simétrico das duas personagens: Joana com sua viagem sem rumo certo e Virgínia com sua viagem de ida e volta entre o campo e a cidade. Em A cidade sitiada, têm-se as traições de Lucrécia a São Geraldo e sua deserção final. Nos três últimos livros (A maçã no escuro, A paixão segundo G.H e Uma aprendizagem), há uma via de peregrinação, seja no itinerário circular de Martim, na descida introspectiva de G.H seja na aprendizagem de Lóri. Em todos esses casos, conclui o crítico, "a errância corresponde, implícita ou explicitamente, a uma busca ética ou espiritual ao longo de uma trajetória, que se apóia ( sic) na figura concreta de uma fuga, com que se alterna e se confunde" (NUNES, 1989, p. 152). O estado de errância é, portanto, definido por essa busca contínua. Isso inicia a partir de um rompimento com determinada ordem de circunstâncias (o meio familiar, os mores locais, as leis, o sistema social), provocado por um desequilíbrio, que parece resultar ora de forças estranhas ao indivíduo, ora ao desejo de liberdade ilimitada que o 
possui, e tendo como consequência a transgressão de códigos, inclusive o linguístico e o religioso.

A esse nomadismo podemos associar também a história do povo judeu e as possíveis interferências judaicas na obra de Clarice Lispector. A própria autora é descendente direta dos judeus e vive uma longa diáspora ${ }^{7}$. Seus pais, refugiando-se da perseguição após a Revolução Bolchevique de 1917, migram para o Brasil, aportando em Maceió em 1921. A menina Haia (depois Clarice Lispector) nasce nesse percurso do leste europeu rumo ao Ocidente. Em 1924, esses refugiados mudam-se para Recife e aí residem por nove anos. Em 1934, por sua vez, a família (sem a mãe que falecera em 1930) transfere-se para o Rio de Janeiro. Já casada, em 1944, Clarice vai habitar em Belém do Pará com o marido. Em seguida, viaja à Europa onde acompanha o esposo diplomata por algumas cidades (Nápoles, Berna, Paris). Em 1949, retornam ao Brasil de férias, mas, no ano seguinte, viajam para Torquay (Inglaterra) e aí residem por seis meses. Em 1951, retornam ao Brasil para, em setembro do ano seguinte, partirem para os Estados Unidos e lá viverem até 1959, quando Clarice separa-se do marido e retorna para o Rio de Janeiro, onde falece em 1977.

Nelson Vieira, num artigo pioneiro sobre “A expressão judaica na obra de Clarice Lispector" (1989), afirma que há, na escrita lispectoriana, certa afinidade com a literatura e a cultura hebraica. Para o autor, "o emprego de mitos judaicos reflete também uma intuição com a cultura e o pensamento hebraico, evidente em seu último livro" (VIEIRA, 1989, p. 207). Para Berta Waldman (2003), o judaísmo, em Clarice Lispector, está presente tanto nos movimentos circulares de sua linguagem, quanto na forma como se inscreve o silêncio em sua obra e na constante presença de referência aos textos bíblicos. Já Dany Kanaan (2003) afirma que os elementos da tradição judaica aparecem na ficção clariciana através da insistência na temática das origens, dos rituais de passagem, da busca, dos desencontros, da revelação de uma verdade, de uma espera constante, do destino. Além da tradição judaica, a obra lispectoriana faz menção constante à tradição cristã, mas não privilegia uma em relação à outra. Aqui encontramos os temas do êxodo, da errância e do exílio tão caros ao povo judeu que estão diretamente ligados ao tema da procura, da busca. Vemos despontar em Perto do coração selvagem o nascimento de um

\footnotetext{
${ }^{7}$ Yudith Rosenbaum (2002) fala de uma diáspora pessoal em Clarice Lispector de duas naturezas: interior e exterior.
} 
novo êxodo que será reescrito ou reatualizado tanto no universo biográfico quanto no ficcional da autora.

A história do povo judeu é totalmente marcada por saídas, errâncias, exílios e buscas. Desde a fundação do Judaísmo, esse povo tem nas viagens seu ponto de partida. Abraão, ao receber o chamado divino, parte de Ur da Caldéia, na Babilônia, para Canaã e depois para o Egito, por volta de 1700 a.C. Os três patriarcas (Abraão, Isaque e Jacó) vivem constantemente em travessias. Do Egito, perseguido pelo faraó, o povo hebreu, guiado por Moisés, fugiu em busca da Terra Prometida, atravessando o Mar Vermelho. Nesse percurso, vagueia pelo deserto durante quarenta anos. Entre 1200 a 1000 a. C., temse o estabelecimento das tribos nômades hebraicas na terra verde de Canaã, numa conquista lenta e árdua (período de formação do povo de Israel). No período compreendido entre os anos 1000 a 587 a. C., o povo de Israel vive a monarquia, quando é governado por Saul, Davi e Salomão. Essa é a fase da autodeterminação nacional, conforme John Bright (2003). A unificação das doze tribos não se sustenta por muito tempo. Após o reinado de Salomão, formam-se dois grupos: o do Norte (Israel, que dura aproximadamente 200 anos, sendo depois conquistado pelos assírios, quando desaparece da história); o do Sul (Judá, tomado depois pelos babilônios). Depois disso, os judeus (o grupo do Sul) são deportados para a Babilônia (período do exílio) e aí vivem por quase 50 anos de muito sofrimento e subjugação. "De um golpe, sua existência nacional terminou e, com ela, todas as instituições sobre as quais sua vida de corporação se tinha expressado: nunca mais Israel seria recriado precisamente da mesma forma" (BRIGHT, 2003, p. 411). Ciro conquista a Babilônia (539 a. C.) e os judeus voltam à sua pátria, tentando retomar suas vidas. Reconstroem o templo, fazem resistência aos gregos (sob a liderança dos Macabeus), mas com poucos resultados. Em 63 a. C., começa o domínio dos povos romanos que, no ano 70 d.C. destroem o templo novamente, dispersando o povo mais uma vez. Os judeus, espalhados pelo mundo, viviam, na Idade Média, em guetos, marginalizados e perseguidos. Criam-se leis antijudaicas, isolando-os e humilhando-os. Considerados como párias, muitas vezes, são obrigados a usar trajes ou insígnias especiais. No final do século XIX, eles são expulsos da Rússia, Polônia e demais países do Leste europeu. Durante a Segunda Guerra Mundial, esses povos foram dizimados em milhões por Hitler nas câmaras de gás e aqueles que escaparam não tinham para onde ir. Com a criação do estado de Israel em 1948, os judeus puderam, enfim, retornar ao seu lar. 
Ao trazer à cena ficcional personagens erráticos e nômades, Clarice Lispector dá continuidade a essas histórias de diáspora e de dispersão, a história de seus pais, de seus antepassados e a sua própria história. Mas a diáspora, na obra de Clarice, é mais acentuada do ponto de vista subjetivo. Em sua ficção, os sujeitos constituem-se no conflito, na fragmentação e na descontinuidade. Erram ao mergulharem em si mesmos, à procura de uma terra jamais encontrada. "Ela errava tanto" (LISPECTOR, 1998, p. 101). São estrangeiros e exilados em seus mundos interiores, incompreensíveis e estranhos a si mesmos. "[...] o exílio é, passa a ser ou sempre foi, sobretudo interior e não determinado por qualquer tipo de deslocação no espaço. É dentro de nós mesmos que existe a terra desconhecida" (SOUSA, 2004, p. 183). Segundo Sousa (2004), o tema do exílio assume um papel determinante em qualquer leitura que se faça do percurso de Clarice Lispector. Em uma carta enviada a Lúcio Cardoso em 13 de julho de 1941, de Belo Horizonte, Clarice comunica-lhe que havia encontrado uma turma de colegas da faculdade que estavam em excursão e fala que isso irá amenizar seu estado de exilada. "Encontrei uma turma de colegas de Faculdade em excursão universitária. Meu exílio se tornará + suave, espero" (LISPECTOR, 2002, p. 16). Numa outra carta enviada ao amigo Fernando Sabino, Clarice externaliza-lhe o sentimento de não pertencimento: “[...] Está me acontecendo uma coisa tão esquisita: com o tempo passando, me parece que não moro em nenhum lugar, e que nenhum lugar "me quer"' (SABINO; LISPECTOR, 2003, p. 134). Nesse sentido, o tema da errância embaralha biografia e ficção em Clarice Lispector, incrustando-se como um topos em sua obra a partir do primeiro romance.

\section{3) PERTO DO CORAÇÃO SELVAGEM: ERRÂNCIA INAUGURAL}

A errância se dá, em Perto do coração selvagem, a partir de três registros. O primeiro dele e o mais central é o que se estabelece entre Joana e o objeto de seu desejo. Nesse romance, há tentativas reiteradas e fracassadas de relação objetal, provocando uma série de repetições (SILVA, 2015). Toda a narrativa se desenvolve em torno dessa relação, quando a heroína insiste em atingir o coração selvagem que se aproxima e se distancia concomitantemente, produzindo uma tensão irreconciliável. Semelhante a Íxion e a Tântalo em seus suplícios sempre repetidos, a protagonista lispectoriana move-se entre o desejo e a sua insatisfação, sem jamais encontrar algo definitivo capaz de apaziguar sua 
fome, porque "Não existe objeto que satisfaça plenamente o desejo e é justamente por isso que ele não para de renascer de cada pequena satisfação, de cada pequeno repouso; é justamente por isso que a vida é tensão permanente, é movimento permanente". (KEHL, 1987, p. 477)

Essa relação inconclusa com o objeto se dá a partir da infância, quando Joana aparece dominada por uma pulsão que a inquieta e procura no pai uma resposta para suas demandas, mas não encontra. Joana continua deslizando sobre as coisas, sem jamais tocar o impossível: "Esse era um de seus segredos. Nunca se permitiria contar, mesmo a papai, que não conseguia pegar 'a coisa"” (LISPECTOR, 1998, p. 16). Como a raposa da fábula, Joana salta continuamente sobre as uvas (coração selvagem, o absoluto do desejo, a Coisa), voltando também com as mãos vazias. Diferente do animal da fábula, a heroína clariciana não desdenha do objeto nem desiste do salto, das tentativas de abocanhar o objeto desejado. Do contrário, reconhece que não pode tocar as uvas, mas continua obstinada, saltando em direção aos frutos, repetindo entre dores e prazeres o ato que saciaria sua fome. Ou talvez sua satisfação venha mesmo desse ato reiterado de pular em direção ao fruto, sem que ele seja tocado, tentando tamponar um vazio estrutural, enredada em "trilhos eternamente estendidos para o desejo de outra coisa". (LACAN, 1998, p. 522)

Para lidar com esse desencontro, Joana foge para as fantasias, por meio das brincadeiras, logrando a frustração e, como o escritor em seu ofício, erige formas que dão contornos ao seu desejo insatisfeito. É no brincar/criar que a heroína/artista burla a frustração e se porta como ser de totalidade, Titã que desafia o lugar de falta, como fica claro na cena abaixo.

Inventou um homenzinho do tamanho do fura-bolos, de calça comprida e laço de gravata. Ele usava-o no bolso da farda de colégio. O homenzinho era uma pérola de bom, uma pérola de gravata, tinha a voz grossa e dizia de dentro do bolso: 'Majestade Joana, podeis me escutardes um minuto, só um minuto podereis interromperdes vossa sempre ocupação?' E declarava depois: 'Sou vosso servo, princesa. É só mandar que eu faço’. (LISPECTOR, 1998, p. 15)

O desejo, na perspectiva psicanalítica, opera metonimicamente sobre os objetos do mundo, procurando substitutos capazes de representar o traço um dia perdido na experiência mítica de satisfação, inscrito na memória inconsciente do sujeito. Nesse deslizamento, o sujeito constrói laços afetivos movido pelo fenômeno transferencial. Em Perto do coração selvagem, o fenômeno da transferência aparece como elemento de 
ligação entre as personagens, enlaçando-as em seus afetos e moldando as suas relações cotidianas. Joana substitui, metonimicamente, o desejo pelo pai numa relação transferencial: do pai ao professor, do professor a Otávio, de Otávio ao homem-amante com quem ela se encontra clandestinamente. Sem que haja um reencontro com o objeto faltoso de forma consistente, a pulsão não se fixa em nenhum deles e o desejo, afirmado a todo custo, continua a deslizar, numa viagem sem rumo certo, mas que tem na assertiva lacaniana de "não ceder do desejo" o ponto central. A protagonista não abre mão de desejar, não cede em sua procura e parte, assegurando a possibilidade de enunciar a vontade, de manter-se viva em sua fratura subjetiva. Os homens, do contrário, são seres no horizonte da queda, no sentido de não conseguirem sustentar o ideal de amor para Joana. Cai o ideal e resta a imagem fracassada do objeto de desejo. Nenhum deles mantem-se na posição ideal para a heroína, que está sempre sedenta por outras fontes, numa postura obsessiva de abandono contínuo dos objetos de desejo. "Ando, deslizo, continuo, continuo... Sempre, sem parar, distraindo minha sede cansada de pousar num fim" (LISPECTOR, 1998, p. 67-8). Consequentemente, Joana vive no devir, no intervalo entre a satisfação e a frustração do desejo.

A errância também se dá, nesse livro, de forma espacial. Embora esses deslocamentos geográficos ocorram de modo ainda incipiente, eles estão relacionados com a inquietação que domina Joana. Portanto, a errância espacial é também resultado da errância objetal. Os deslocamentos da personagem se dão, inicialmente, da casa paterna para a casa da tia, quando a menina se torna órfã e passa a viver na estranheza de outro $\operatorname{lar}^{8}$.

A casa da tia era um refúgio onde os ventos e a luz não entravam. A mulher sentou-se com um suspiro na sombria sala de espera, onde, entre os móveis pesados e escuros, brilhavam levemente os sorrisos dos homens emoldurados. Joana continuou de pé, mal respirando aquele cheiro morno que após a maresia forte vinha doce e parado. Mofo e chá com açúcar. (LISPECTOR, 1998, p. 36)

A atmosfera pesada e imóvel da casa parental encurrala a menina que, aos poucos, vai-se revelando estranha e independente, a ponto de causar medo na própria tia: “ela é sempre calada, como se não precisasse de ninguém... E quando olha é bem nos olhos, pisando a gente." (LISPECTOR, 1998, p. 50) A partir disso, resolvem colocá-la num

\footnotetext{
${ }^{8}$ Clarice também, em sua história pessoal, viveu esse estranhamento na casa alheia, nos lugares onde experimentou a desterritorialização. Suas cartas e crônicas são testemunhas disso.
} 
internato, efetuando outro deslocamento na vida de Joana. Desse tempo, nascem as relações com o professor em quem a moça encontra amparo e suporte para algumas de suas demandas. Nesse período, os deslocamentos espaciais convergem para a casa do mestre, onde Joana se depara com outro empecilho: os ciúmes da esposa do docente. A casa, na narrativa inaugural, longe de se tornar locus de afeto e acolhimento, é o reduto da solidão e do conflito, anunciando aquilo que se tornará mais acentuado em Laços de família, coletânea de contos publicada por Lispector em 1960.

Do internato, Joana muda-se para a casa de Otávio, com quem contrai matrimônio e mantém uma relação de desencontro amoroso, porque Joana "Desejava ainda mais: renascer sempre, cortar o que aprendera, o que vira, e inaugurar-se num terreno novo onde todo pequeno ato tivesse um significado, onde o ar fosse respirado como da primeira vez” (LISPECTOR, 1998, p. 80). Otávio é o que “cede de seu desejo”, o homem cansado que desiste de investir em novos projetos, de procurar a vida em sua tragicidade. É apenas um homem de braços cruzados que espera encontrar em Joana aquilo que ele não tem: "Não era como mulher, não era assim, cedida, que ele a queria... Precisava-a fria e segura. [...] E forte, para ensinar-lhe a não ter medo". (LISPECTOR, 1998, p. 96)

Após a separação com Otávio, Joana estabelece uma relação breve com um desconhecido, que também não se sustenta. E continua seu périplo, numa viagem que finaliza o livro. Isso constitui a última alternativa de um sujeito encurralado pelo desejo. De certa forma, toda a vida de Joana se configura numa viagem de regresso, de retorno ao real, para além de toda representação. (SILVA, 2013)

Por fim, a errância reverbera-se na própria estrutura do romance, que mimetiza o movimento do desejo em torno do objeto jamais atingido. Os títulos dos capítulos da primeira parte apresentam esse anseio do sujeito que se move cambiante entre a posse e a alucinação da coisa. Há uma alternância na forma dos títulos. O primeiro chama-se "O pai"; o segundo, "O dia de Joana"; o terceiro, “A mãe" e o seguinte, "O passeio de Joana". Observe que, no primeiro, há apenas a nomeação da coisa (somente sintagma nominal) enquanto que, no seguinte, há o sintagma nominal acompanhado de outro sintagma preposicional com valor de adjunto adnominal, indicativo de posse (de Joana). Isso encena a possível captura (ainda que fantasmagórica) do objeto metonímico pelo desejo. $\mathrm{Na}$ segunda parte, essa posse torna-se rarefeita, como se acenasse para o deslizamento contínuo da vontade sobre as coisas e antecipasse ao leitor o trajeto inconcluso da personagem. Os adjuntos adnominais aparecem em alguns títulos, porém não mais dizem respeito à posse do objeto relativo ao desejo de Joana (“O abrigo no professor", "O 
encontro de Otávio", "O abrigo no homem" e "A partida dos homens"). O que encontramos, nessa segunda parte do romance, é uma tentativa de abrigo (repetido em dois títulos), vontade de repouso que se revela incapaz de obturar, por completo, a hiância subjetiva da protagonista, jogando-a, mais uma vez, numa "saída indiscreta pela porta dos fundos". E o romance finaliza com duas partidas simbólicas: a primeira, a dos homens (“A partida dos homens”) e a segunda e última, a da heroína (“A viagem”), acenando para o deslocamento desejante em direção a um significante que abarque o coração selvagem, um traço de sentido que presentifique a coisa perdida para sempre.

Ainda nesse plano, a autora utiliza uma série de recursos estilísticos que mimetizam essa tensão inconclusa e a errância objetal no romance. As antíteses, as apóstrofes, os travessões, os símiles e - sobretudo - as repetições apontam, conforme Olga de Sá (2000) para o núcleo da busca da personagem. Por meio desses recursos, Clarice constrói uma narrativa esgarçada, concebida pela crítica como romance inacabado, incompleto ou ainda como romance moderno. Segundo Benedito Nunes (2009), Lispector pessoalizou e singularizou a tendência da ficção moderna entre nós. Representante daquilo que Rosenfeld chamou de romance moderno, o livro apresenta os traços apontados pelo crítico, como o abalo da cronologia e da continuidade, o esgarçamento da causalidade lógica a partir da ruptura das categorias espaço e tempo e o desfazimento da personagem nítida e de contornos firmes e claros. [...] "Devido à focalização ampliada de certos mecanismos psíquicos perde-se a noção da personalidade total e de seu caráter que já não pode ser elaborado de modo plástico, ao longo de um enredo em sequência causal, através de um tempo de cronologia coerente" (ROSENFELD, 2006, p. 85). Não há mais a representação de retratos íntegros de indivíduos, mas imagens borradas de sujeitos fragmentados, traços errantes de uma individualidade problemática. A pessoa humana é desmontada juntamente com sua certeza cartesiana. E a forma romanesca sofre o abalo dessa fragmentação.

\section{CONSIDERAÇÕES FINAIS}

Perto do coração selvagem é nascedouro de muitos temas que serão recorrentes na produção ficcional de Clarice Lispector: a inquietação, o drama da linguagem, a morte, o fazer literário, os conflitos subjetivos, os laços de família, a agressividade, o gesto afirmativo da vida, o desejo, a viagem. Nessa obra também emerge, como vimos, o tema da errância, quando a autora atualiza, em Joana, o mito do Judeu errante. 
A ideia aqui defendida é que o livro inaugural de Clarice Lispector é um romance de errância subjetiva, porque o nomadismo se dá, sobretudo, no mundo interior da personagem. Movida por uma inquietação que a consome, Joana faz um percurso sem fim ao longo da narrativa. Nesse périplo, há uma aprendizagem, porque a heroína aprende a lidar com a solidão e com sua tragédia pessoal. Desse aprendizado, resulta a aceitação da vida em sua condição mesma de devir.

Para defender essa tese, apresentei três modulações dessa errância que se dão no livro em pauta. A relação de objeto que se estabelece entre o desejo de Joana e as suas escolhas leva a personagem sempre ao desencontro, a uma busca malograda que não termina. Há algo em Joana do campo da compulsão, redundando em um gesto obsessivo: "Há qualquer coisa que roda comigo, roda, roda, me atordoa, me atordoa, e me deposita tranquilamente no mesmo lugar" (LISPECTOR, 1998, p. 147). Ao mesmo tempo em que ela que não atinge a coisa, renasce o desejo de investir mais uma vez, outra vez, sempre. Dessas investidas à procura do selvagem coração da vida, resultam alguns movimentos externos realizados pela menina. Estamos aqui no âmbito da segunda modulação: a da errância espacial. Nesses deslocamentos, Clarice aprofunda a solidão e o desamparo de Joana para sustentar a tese presente na epígrafe recolhida de Joyce. Apesar de só, restalhe a felicidade que a acompanha no gesto que encerra a narrativa.

A narrativa inicial de Clarice Lispector também mimetiza, na própria linguagem, a errância de Joana. É como se a inquietação subjetiva se espalhasse pela sintaxe, tomada por paradoxos, comparações, metáforas e, principalmente, por repetições. Para tentar alcançar a coisa, o objeto do desejo, a linguagem tenta cercá-lo de todo modo. Entretanto, como Joana, ela também fracassa, porque "As palavras são seixos rolando no rio" (LISPECTOR, 1998, p. 194) e por meio delas, "Nada posso dizer ainda dentro da forma". (LISPECTOR, 1998, p.69)

Portanto, a partir dessas estratégias, Clarice Lispector faz emergir o topos da errância em seu primeiro romance que será continuado nas obras posteriores, tanto no aspecto subjetivo quanto no aspecto externo. Apesar dos constantes deslocamento a que estão submetidas suas personagens, prevalece a desterritorialização interior, o exílio de alma, gerando uma narrativa tensionada pela busca de um objeto que é sempre outro. 


\section{Referências}

BRIGHT, John. História de Israel. Tradução de Luiz Alexandre Rossi e Eliane Cavalhere Solano Rossi. 7. ed. São Paulo: Paulus, 2003.

CANDIDO, Antonio. No raiar de Clarice Lispector. In: Vários escritos. 2. ed. São Paulo: Livraria Duas Cidades, 1977. p. 125 - 31.

CHEVALIER, Jean; GHEERBRANT, Alain. Dicionário de símbolos: mitos, sonhos, costumes, gestos, formas, figuras, cores, números. Tradução Vera da Costa e Silva et all. 20. ed. Rio de janeiro: José Olympio, 2006.

EDLER, Sandra. Luto e melancolia: à sombra do espetáculo. Rio de Janeiro: Civilização Brasileira, 2008. (Para ler Freud).

KANAAN, Dany Al-Behy. À escuta de Clarice Lispector: entre o biográfico e o literário: uma ficção possível. São Paulo: EDUC, 2003.

KEHL, Maria Rita. A psicanálise e o domínio das paixões. In: CARDOSO, Sérgio et all. Os sentidos da paixão. São Paulo: Companhia das Letras, 1987. p. 469- 96.

LACAN, Jacques. O Seminário, Livro 7: a ética da psicanálise. Tradução de Antônio Quinet. Rio de Janeiro: Jorge Zahar Editores, 1997. . O estádio do espelho como formador da função do eu. In:

Escritos. Tradução de Vera Ribeiro. Rio de Janeiro: Jorge Zahar Ed., 1998. p. 96-103. O seminário, Livro 6: O desejo e sua interpretação. Porto Alegre: Associação Psicanalítica de Porto Alegre, 2002.

LISPECTOR, Clarice. Água viva: ficção. 2. ed. Rio de Janeiro: Artenova, 1973. Laços de família. 29. ed. Rio de Janeiro: Francisco Alves, 1997.

_. A legião estrangeira: contos. Rio de Janeiro: Rocco, 1999. Perto do coração selvagem. Rio de Janeiro: Rocco, 1998. . Correspondências. Org. Teresa Montero. Rio de Janeiro: Rocco, 2002.

MCKENZIE, John L. Dicionário bíblico. Trad. Álvaro Cunha et all. 10. ed. São Paulo: Paulus, 2011.

NIETZSCHE, Friedrich. A vontade de poder. Tradução de Marcos Sinésio Pereira Fernandes e Francisco José Dias de Moraes. Rio de Janeiro: Contraponto, 2008. . A gaia ciência. Tradução de Paulo César de Souza. São Paulo: Companhia das Letras, 2001.

NUNES, Benedito. A narração desarvorada. In: Cadernos de Literatura Brasileira, n 17/18. São Paulo: Instituto Moreira Sales, dez, 2004, p. 292-301. 
O drama da linguagem: uma leitura de Clarice Lispector. 2. ed. São Paulo: Ática, 1989.

A clave do poético. (Org. Victor Sales Pinheiro). São Paulo: Companhia das Letras, 2009.

ROSENBAUM, Yudith. Clarice Lispector. São Paulo: Publifolha, 2002. (Folha explica).

Metamorfoses do mal: uma leitura de Clarice Lispector. São Paulo: Editora da Universidade de São Paulo: Fapesp, 2006. (Estudos de Cultura; 17).

ROSENFELD, Anatol. Reflexões sobre o romance moderno. In:

Texto/Contexto I. São Paulo: Perspectiva, 2006, p. 75-97. (Debates, 7).

ROUART, Marie-France. O mito do Judeu Errante. In: BRUNEL, Pierre (Org.). Dicionário de mitos literários. Trad. Carlos Sussekind et all. 4. ed. Rio de Janeiro: José Olympio, 2005. p. 665-72.

SÁ, Olga de. A escritura de Clarice Lispector. 3. ed. Petrópolis: Vozes, 2000.

SABINO, Fernando; LISPECTOR, Clarice. Cartas perto do coração. 5. ed. Rio de Janeiro: Record, 2003.

SILVA, Gilson Antunes da. Desejo e solidão: uma leitura do romance de Clarice Lispector. Curitiba: Appris, 2018.

Cantilenas afirmativas: a poética da repetição de Clarice Lispector. 2015, 257f.Tese (Doutorado em Literatura e Cultura) - Instituto de Letras - Programa de PósGraduação em Literatura e Cultura, Universidade Federal da Bahia, Salvador, 2015. A viagem, o desejo e a afirmação da vida em Perto do coração selvagem. Revista Estação Literária, Londrina, v. 10C, p. 123-38, fev.2013. Disponível em http://www.uel.br/pos/letras/EL/vagao/EL10C-Art9.pdf. Acesso em 09 jul. 2014.

SOUSA, Carlos Mendes de. Clarice Lispector: figuras da escrita. São Paulo: Instituto Moreira Salles, 2012.

Escrever o âmago. In: PONTIERI, Regina (Org.). Leitores e leituras de Clarice Lispector. São Paulo: Hedra, 2004, p. 175-90.

VIEIRA, Nelson H. A expressão judaica na obra de Clarice Lispector. Campinas: Remate de Males, ${ }^{\circ}$ 09, p. 207-09, 1989.

WALDMAN, Berta. Entre passos e rastros: presença judaica na literatura brasileira contemporânea. São Paulo: Perspectivas: FAPESP, 2003 (Estudos). 


\title{
NEAR TO THE WILD HEART, BY CLARICE LISPECTOR: \\ A NOVEL OF SUBJECTIVE ERRANCY
}

\begin{abstract}
As an object of study, I take Clarice Lispector's novel, Near to the Wild Heart, in order to highlight how Joana's choices for the adventure of the path reverberate the myth of the Wandering Jew and, at the same time, outline the topos of wandering in the author's fictional work. I read Lispector's inaugural poetics as a novel of subjective errancy and then highlight three aspects of the subjective diaspora that are present in the work: errancies in object, in space and structure.
\end{abstract}

\section{Keywords}

Near to the Wild Heart. Clarice Lispector. Novel of subjective errancy. 